\title{
Pharmacology of MDMA- and Amphetamine-Like New Psychoactive Substances
}

Linda D. Simmler ${ }^{1 *}$ and Matthias E. Liechti ${ }^{2 \star}$

Linda D. Simmler $(\bowtie)$

${ }^{1}$ Department of Basic Neurosciences, University of Geneva, Rue Michel-Servet 1, CH1205 Geneva, Switzerland

e-mail: linda.simmler@unige.ch

2 Matthias E. Liechti $(\bowtie)$

Division of Clinical Pharmacology and Toxicology, University Hospital Basel, Schanzenstrasse 55, CH-4056 Basel, Switzerland

e-mail: matthias.liechti@usb.ch

\section{Contents}

1. Introduction. 


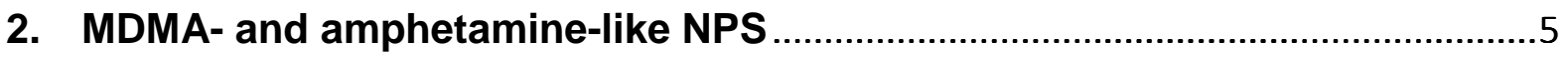

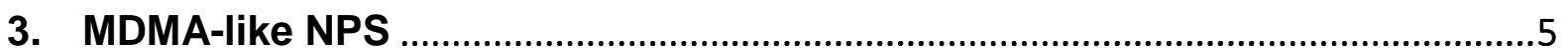

3.1. Pharmacology of MDMA-like substances

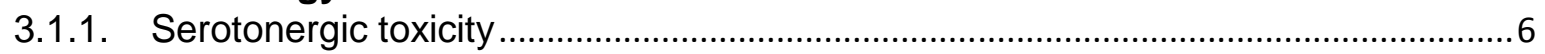

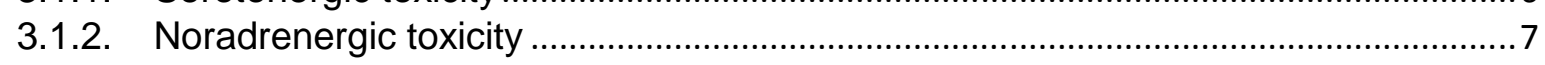

3.2. MDMA-like amphetamine derivatives

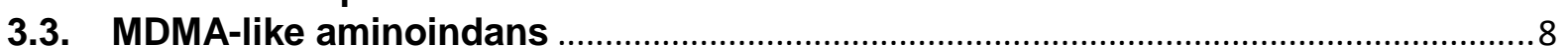

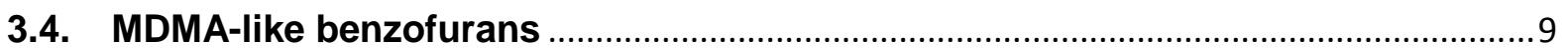

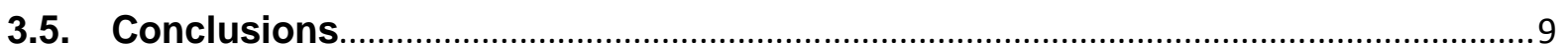

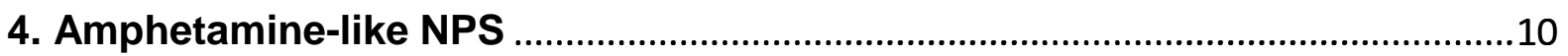

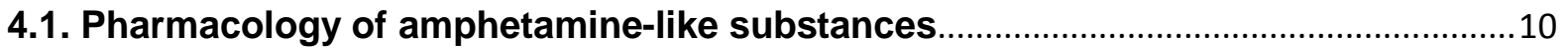

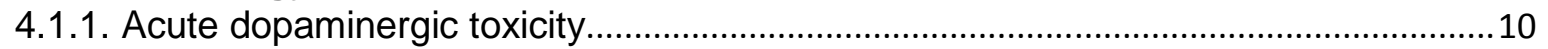

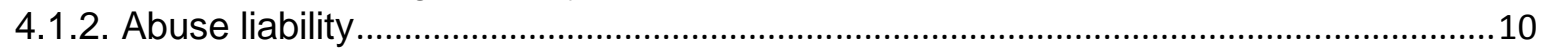

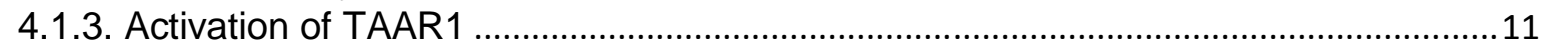

4.2. 4-Fluoroamphetamine, 4-fluoromethamphetamine and $\mathrm{N}$-ethylamphetamine .....11

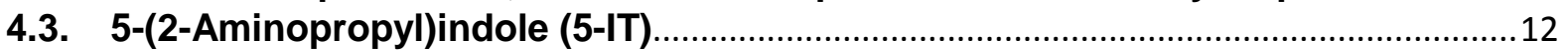

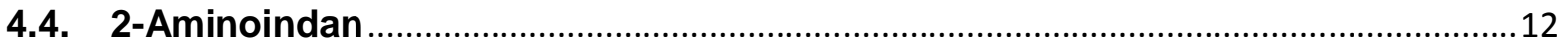

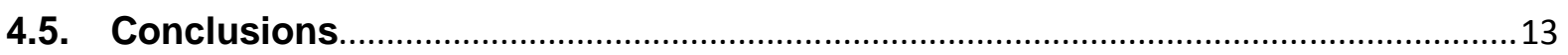

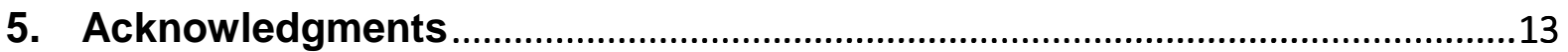

\begin{abstract}
New psychoactive substances (NPS) with amphetamine-, aminoindan-, and benzofuran basic chemical structures have recently emerged for recreational drug use. Detailed information about their psychotropic effects and health risks is often limited. At the same time, it emerged that the pharmacological profiles of these NPS resemble those of amphetamine or MDMA. Amphetamine-like NPS induce psychostimulation and euphoria mediated predominantly by norepinephrine (NE)- and dopamine (DA) transporter (NET and DAT) inhibition and transporter-mediated release of NE and DA, thus, showing a more catecholamine-selective profile. MDMAlike NPS frequently induce well-being, empathy, and prosocial effects and have only moderate psychostimulant properties. These MDMA-like substances primarily act by inhibiting the serotonin (5-HT) transporter (SERT) and NET, also inducing 5-HT and NE release. Monoamine receptor interactions vary considerably among amphetamineand MDMA-like NPS. Clinically, amphetamine- and MDMA-like NPS can induce sympathomimetic toxicity. The aim of this chapter is to review the state of knowledge
\end{abstract}


regarding these substances with a focus on the description of the in vitro pharmacology of selected amphetamine- and MDMA-like NPS. In addition, it is aimed to provide links between pharmacological profiles and in vivo effects and toxicity, which leads to the conclusion that abuse liability for amphetamine-like NPS may be higher than for MDMA-like NPS, but that the risk for developing the life-threatening serotonin syndrome may be increased for MDMA-like NPS.

\section{Keywords}

Aminoindans; amphetamine, benzofurans; DAT; dopamine; 4-fluoroamphetamine; 4FA; 5-IT; NET; noradrenaline; NPS; MDMA; monoamines; release; serotonin; SERT; uptake

\section{Acronyms of the Discussed New Psychoactive Substances (NPS)}

\begin{tabular}{|c|c|}
\hline $2-\mathrm{Al}$ & 2-Aminoindane \\
\hline 3-MMC & 3-Methyl- $N$-methylcathinone \\
\hline 4-APB & 4-(2-Aminopropyl)benzofuran \\
\hline $5-\mathrm{APB}$ & 5-(2-Aminopropyl)benzofuran \\
\hline $6-\mathrm{APB}$ & 6-(2-Aminopropyl)benzofuran \\
\hline 7-APB & 7-(2-Aminopropyl)benzofuran \\
\hline $5-A P D B$ & 5-(2-Aminopropyl)-2,3-dihydrobenzofuran \\
\hline 6-APDB & 6-(2-Aminopropyl)-2,3-dihydrobenzofuran \\
\hline 5 -EAPB & 5-(2-Ethylaminopropyl)benzofuran \\
\hline 4-FA & 4-Fluoroamphetamine \\
\hline $5-\mid \mathrm{AI}$ & 5-lodoaminoindan \\
\hline 5-IT, 5-API & 5-(2-Aminopropyl)indole \\
\hline 4-MA & 4-Methylamphetamine \\
\hline 5-MAPDB & 1-(2,3-Dihydrobenzofuran-5-yl)- $N$-methylpropan-2-amine \\
\hline MBDB & 3,4-Methylenedioxyphenyl- $N$-methyl-2-butanamine \\
\hline MDA & 3,4-Methylenedioxyamphetamine \\
\hline MDAI & 3,4-Methylenedioxyaminoindan \\
\hline MDEA & 3,4-Methylenedioxy- $N$-ethylamphetamine \\
\hline MMAI & 5-Methoxy-6-methyl-2-aminoindan \\
\hline 4-MTA & 4-Methylthioamphetamine \\
\hline PMA & para-Methoxyamphetamine \\
\hline PMMA & para-Methoxymethamphetamine \\
\hline
\end{tabular}




\section{Introduction}

Amphetamine and its derivative 3,4-methylenedioxymethamphetamine (MDMA) are substances that have been abused for decades. Amphetamine, and alternatively methamphetamine are typically sold under the street name "speed", and MDMA is the substance typically associated with "ecstasy" pills. Although MDMA is a 3,4methylenedioxy derivative of amphetamine, the subjective effects as well as the pharmacological profiles of MDMA and amphetamine are distinct. Psychostimulation and euphoria are commonly described acute subjective effects of amphetamine consumption (Dolder et al. 2017). MDMA is the prototypical entactogenic/empathogenic drug (Nichols 1986) and induces fewer psychostimulant effects than amphetamine (Bershad et al. 2016). Enhancement of feelings of love, happiness, and closeness to others are typical entactogenic effects (Hysek et al. 2014a; Hysek et al. 2014b; Liechti et al. 2001). Amphetamine and MDMA act on monoamine re-uptake transporters (Simmler et al. 2013; Verrico et al. 2007). By blocking the serotonin (5-HT), dopamine (DA), and norepinephrine (NE) transporters (SERT, DAT, and NET, respectively), re-uptake of the respective neurotransmitters is prevented, causing increased neurotransmitter concentrations in the synaptic cleft (Kehr et al. 2011; Torres et al. 2003). Amphetamine derivatives typically also induce transporter-mediated release of neurotransmitters (Blakely et al. 2005; Hysek et al. 2012c). Since the neurotransmitters 5-HT, DA, and NE are differentially involved in modulating behavior and subjective effects, distinct pharmacological profiles of drugs of abuse can be linked to specific psychotropic effects and intoxication (Dolder et al. 2017; Liechti 2015; Schmid et al. 2014). As such, amphetamine with preference for human DAT and NET is experienced differently than MDMA, which, in contrast, preferentially acts at human SERT and NET vs. DAT (Simmler et al. 2013).

The chemical diversity found among substances commonly referred to as new psychoactive substances (NPS) is quite pronounced. Over 600 different NPS have emerged on the illicit drug market since the beginning of this century (EMCDDA 2016). The pharmacology and psychotropic effects range widely among amphetamine-based NPS. For example, subjective effects induced by NPS based on the amphetamine template may range from hallucinogenic via entactogenic to stimulant properties predominantly depending on the nature and location of substituents on the phenyl ring (Hill and Thomas 2011; Liechti 2015; Zwartsen et al. 2017; Nichols 2017) In addition, many amphetamine-based NPS carry a keto group on the B-position of the carbon side chain, thus, giving rise to the cathinone template (Figure 1) (Prosser and Nelson 2012), Cathinone NPS are discussed in detail in the preceding chapter of this book. The present chapter will focus on non-ß-keto NPS that resemble amphetamine and MDMA in their pharmacology and subjective effects. The main focus of this chapter is the description of the in vitro pharmacology of selected amphetamine- and MDMA-like NPS, with the additional aim to provide links between pharmacological profiles and in vivo effects and toxicity.

By using the terms amphetamine- and MDMA-like NPS, we refer mostly to pharmacological profiles that are comparable to amphetamine and/or MDMA. Pivotal are the relative potencies for inhibition of the human SERT, DAT, and NET. Furthermore, characteristic for amphetamine- and MDMA-like substances is that they induce transporter-mediated release of monoamines. Release is typical for amphetamine and MDMA and distinguishes amphetamine-derivatives from pure uptake blockers such as cocaine or the NPS 3,4-methylenedioxypyrovalerone (MDPV; Baumann et al. 2013). Our classification of NPS as amphetamine- or MDMA-like is 
mainly based on the relative activity for uptake inhibition at DAT $v s$. SERT, referred to as DAT/SERT ratio. DAT/SERT ratios are calculated as $\mathrm{IC}_{50}$ value for SERT divided by $\mathrm{IC}_{50}$ value for DAT (also as $1 /\left(\right.$ DAT IC $_{50}$ ) divided by $1 /\left(\mathrm{SERT} \mathrm{IC}_{50}\right)$ ). DAT/SERT ratios can also be calculated for $E_{50}$ values for transporter-mediated release (Baumann et al. 2012; Marusich et al. 2016). MDMA acts preferentially on SERT, reflected in a low DAT/SERT ratio. In contrast, amphetamine acts preferentially on DAT, reflected in a high DAT/SERT ratio (Simmler et al. 2013). Below we will discuss the pharmacology and psychotropic effects of amphetamine-like and MDMA-like NPS separately.

\section{MDMA- and amphetamine-like NPS}

The amphetamine-derivatives discussed in this chapter are $\mathrm{N}$-ethylamphetamine, 4fluoroamphetamine (4-FA), 4-fluoromethamphetamine, 5-(2-aminopropyl)indole (5-IT, also known as 5-API), 4-methylamphetamine (4-MA), 3,4-methylenedioxyphenyl- $N$ methyl-2-butanamine (MBDB), 3,4-methylenedioxyamphetamine (MDA), 3,4methylenedioxy- $N$-ethylamphetamine (MDEA), 4-methylthioamphetamine (4-MTA), para-methoxyamphetamine (PMA), and para-methoxymethamphetamine (PMMA). Aminoindans discussed are 2-aminoindane (2-AI), 5-iodoaminoindan (5-IAI), 3,4methylenedioxyaminoindan (MDAI), and 5-methoxy-6-methyl-2-aminoindan (MMAI). Benzofurans discussed are 4-(2-aminopropyl)benzofuran (4-APB), 5-(2aminopropyl)benzofuran (5-APB), 5-(2-aminopropyl)-2,3-dihydrobenzofuran (5APDB), 5-(2-ethylaminopropyl)benzofuran (5-EAPB), 1-(2,3-dihydrobenzofuran-5-yl)$\mathrm{N}$-methylpropan-2-amine (5-MAPDB), 6-(2-aminopropyl)benzofuran (6-APB), 6-(2aminopropyl)-2,3-dihydrobenzofuran (6-APDB), and 7-(2-aminopropyl)benzofuran (7APB).

If not otherwise noted, we refer to the racemic mixtures of compounds, except for D- or (S)-(+)-amphetamine. The isomers of psychoactive drugs with asymmetric centers can have different biological activity (Baumann et al. 2007). However, since street drugs are produced as racemic mixtures, pharmacological in vitro- or animal studies that use the racemic mixtures of the compounds are representative reflections of street drug activity. Chemical structures of amphetamine, MDMA and selected NPS are shown in Figure 1. Cathinone-derivatives are discussed in the preceding chapter of this book, but the structure of cathinone is displayed in Figure 1 to illustrate the Bketo substituent typical for cathinone-based NPS. 2-Al forms the basic structure of aminoindan-derived NPS, and 5-APB is shown as example for benzofuran NPS.

\section{MDMA-like NPS}

\subsection{Pharmacology of MDMA-like substances}

Several specific ring-substituted amphetamine-based NPS that lack the B-keto substituent resemble MDMA in their pharmacological profile. MDMA-like NPS potently inhibit the NET and SERT with lower potency for DAT inhibition. Accordingly, their DAT/SERT ratio is low, comparable to MDMA, for which our laboratory reported a DAT/SERT ratio of 0.08 (Simmler et al. 2013). DAT/SERT ratios for MDMA below 1 were also reported for release (Eshleman et al. 2017; Marusich et al. 2016; Baumann 
et al. 2012). As for uptake inhibition (Simmler et al. 2013), these studies also report DAT/SERT ratios for amphetamine- or methamphetamine-induced release that are $>150$ times higher than the DAT/SERT ratio of MDMA. A low DAT/SERT ratio predicts MDMA-like subjective effects and a lower dependence potential compared to amphetamine (Suyama et al. 2016; Liechti 2015). MDMA-like pharmacological properties can be found among benzofurans, aminoindans, and amphetamines.

MDMA is a prototypical entactogenic/empathogenic drug that retains some psychostimulant effects. It increases empathy, sociability, closeness to others, but also happiness and self-esteem (Hysek et al. 2014a; Hysek et al. 2014b; Liechti et al. 2001). Cardiostimulant effects are common and include increased blood pressure, increased heart rate, and hyperthermia (Vizeli and Liechti 2017). Bruxism resulting from increased muscle tension is also experienced frequently (Cole and Sumnall 2003). The psychotropic and cardiostimulant effects have been attributed foremost to the 5-HT and NE release properties of MDMA (Hysek et al. 2011; Hysek et al. 2012c). Concomitant to inducing transporter-mediated 5-HT and NE release, MDMA inhibits the re-uptake of the respective neurotransmitters at SERT and NET. MDMA inhibits DAT with significant lower potency than it inhibits NET and SERT. Its low DAT/SERT ratio (0.08; Simmler et al. 2013) is a representative measure for selectivity of SERT over DAT and is used here to compare NPS to MDMA.

MDMA is also a low-potency partial agonist of the 5- $\mathrm{HT}_{2 \mathrm{~A}}$ receptor. Although not frequent, mild hallucinogen-like effects of MDMA have been reported, which may be attributable to 5-HT2A agonism (Nichols 2004; Liechti et al. 2000). MDA, the active metabolite of MDMA (Hysek et al. 2011), shows a 10-fold higher potency for 5- $\mathrm{HT}_{2 \mathrm{~A}}$ agonism than MDMA (Rickli et al. 2015c). MDA likely contributes to the mode of action of MDMA and might contribute to the mild hallucinogenic effects of MDMA.

Binding affinity of MDMA for adrenergic receptors is low, but since MDMA increases NE levels via transporter-mediated NE release and NET uptake inhibition, indirectly NE-mediated effects at adrenergic receptors clearly contribute to MDMA action (Hysek et al. 2011). $\beta$-Adrenoceptors are involved in MDMA-induced increase of heart rate (Hysek et al. 2010). The $\alpha_{1}$ - and $\beta$-adrenoceptors have been implicated in hyperthermia and drug-induced vasoconstriction (Hysek et al. 2012a). $\alpha$ 2AAdrenocepors are associated with sympathomimetic toxicity and augmented NE release (Hysek et al. 2012b). Potent transporter-mediated NE release or even NET inhibition seems sufficient to induce cardiostimulant effects mediated through the different adrenergic receptors (Hysek et al. 2011). NPS with potent effects at NET thus likely induce psychostimulation and sympathomimetic toxicity.

\subsubsection{Serotonergic toxicity}

Increased levels of 5-HT can lead to serotonergic toxicity and, in extreme cases, can result in precipitation of the serotonin syndrome. Typical symptoms of the serotonin syndrome include neuromuscular hyperactivity, clonus, autonomous hyperactivity (including hyperthermia), sweating, agitation and confusion (Gillman 2005; Liechti 2015). MDMA-like drugs typically induce symptoms of serotonergic intoxication, potentially leading to a severe serotonin syndrome including hyperthermia but also a syndrome of inadequate diuretic hormone (SIADH) resulting in hyponatremia (Simmler et al. 2011; Hartung et al. 2002; Holden and Jackson 1996). Hyperthermia, followed by life-threatening complications such as rhabdomyolysis, intravascular coagulation, and organ failure, is commonly involved in fatal intoxications with psychostimulants (Cole and Sumnall 2003). Although hyperthermia is a well-described unwanted effect 
of MDMA (Liechti 2014), the past has shown that certain psychoactive substances induce hyperthermia more readily than MDMA, which has been associated with fatal complications. For example, the more traditional substances PMA, PMMA, and 4-MTA show a selectivity for SERT over DAT similar to MDMA (Table 1) but the morbidity and mortality linked to these particular substances has been observed to be greater and more distinct compared to MDMA (Lurie et al. 2012; Vevelstad et al. 2012). Inhibition of monoamine oxidase (MAO)-A by PMA, PMMA and 4-MTA (Matsumoto et al. 2014), might play a major role in the induction of severe hyperthermia. Increased levels of cytosolic 5-HT, resulting from MAO inhibition, might augment drug-induced release of 5-HT via SERT. The combination of MAO inhibition and 5-HT release, as reported for PMA, PMMA and 4-MTA (Matsumoto et al. 2014), is therefore particularly prone to induce potentially life-threatening serotonergic intoxication. MAO inhibition has been implicated in hyperthermia and the life-threatening serotonin syndrome (Carmo et al. 2003; Gillman 2005). From the use of selective SERT inhibitors as antidepressants, it is well known that the combination of SERT inhibition together with MAO inhibition can cause life-threatening serotoninergic intoxication, including hyperthermia. Testing NPS for the potential of MAO inhibition might therefore warrant further investigation.

\subsubsection{Noradrenergic toxicity}

Sympathomimetic toxicity results from increased activation of the NE system, either via direct activation of adrenergic receptors or indirectly via receptor activation due to increased NE levels (Hysek et al. 2012a; Hysek et al. 2011; Hysek et al. 2010). Hyperthermia, hypertension, tachycardia and agitation are typical symptoms of stimulant-induced noradrenergic toxicity (Cruickshank and Dyer 2009; Cole and Sumnall 2003). Cardiovascular sympathomimetic toxicity is typically associated with amphetamine but also occurs following MDMA administration via induction of NE release and increases in plasma NE levels. NE-mediated hyperthermia involves stimulation of $\alpha_{1}$ - and $B_{3}$-adrenoceptors (Sprague et al. 2004; Hysek et al. 2012a). Mechanistically, hyperthermia occurs by activation of $\alpha_{1}$-adrenoceptors via increased vasoconstriction, leading to decreased heat dissipation. B3-Adrenoceptor activation causes mitochondrial uncoupling, which increases heat generation (Liechti 2014).

\subsection{MDMA-like amphetamine derivatives}

The amphetamine-derivatives MBDB, 4-MA, MDEA, 4-MTA, PMA, and PMMA show uptake inhibition profiles and DAT/SERT ratios similar to MDMA (Table 1). In vivo drug discrimination experiments in rats suggest that PMA, PMMA and 4-MTA show MDMAlike properties (Dukat et al. 2002; Glennon et al. 2007). However, these substances did not substitute for amphetamine in the drug discrimination experiments, which predicts that PMA, PMMA and 4-MTA have less stimulant-like properties than MDMA. The (S)-(+)-isomer of MDMA showed stimulant properties in rats, reflected in hyperlocomotion and substitution for amphetamine in drug discrimination tests (Glennon et al. 1988). 4-MTA, PMA and PMMA have been associated with severe serotonergic toxicity (Liechti 2015). The combination of MAO inhibition and potent 5$\mathrm{HT}$ release properties are likely the cause for the high morbidity and mortality reported for these substances. Similarly, 4-MA is a potent 5-HT releaser (Baumann et al. 2011) and inhibits MAO, and has been associated with fatal intoxications (Blanckaert et al. 2013). Furthermore, 4-MA is a potent partial agonist at the 5-HT2B receptor (Luethi et 
al. 2017). This receptor has been implicated in endocardial fibrosis (Roth 2007) but whether chronic substance use indeed causes such cardiac complications remains to be established.

MDEA, although equal to MDMA for SERT inhibition potency (Table 1), induces hyperthermia in rats less potently than MDMA (Colado et al. 1999). The lower potency at NET compared to MDMA (Table 1) might account for this difference, since NE release plays a crucial role in the induction of drug-induced hyperthermia (Sprague et al. 2004; Hysek et al. 2012a; Liechti 2014). Similarly, MBDB is less potent at NET inhibition than MDMA (Table 1; or in rat synaptosomes IC50(MDMA) $=405 \mathrm{nM}, \mathrm{IC}_{50}$ (MBDB) $=1233$ (Johnson et al. 1991)). MBDB is considered to share a range of psychopharmacological effects also observed with MDMA and drug discrimination studies revealed that MBDB substitutes for MDMA (Aerts et al. 2000). To the best of our knowledge, no studies on the effect of MBDB and MDEA on MAO exist to date.

\subsection{MDMA-like aminoindans}

Aminoindans were originally developed as potential therapeutic bronchodilators, but have emerged in the recent years as NPS among recreational drug users, although with relatively low prevalence (Brandt et al. 2013; Sainsbury et al. 2011). Among the relatively few NPS falling into the aminoindan class, differences in the pharmacological profiles have been described. The aminoindans 5-IAI, MDAI, and MMAI show an MDMA-like uptake inhibition profile with DAT/SERT ratios smaller or equal to 0.2 (Table 1). In contrast, 2-aminoindan (2-Al) and $\mathrm{N}$-methyl-2-Al are selective NET inhibitors and NE releasers, with 2-Al also releasing DA (Simmler et al. 2014b; Luethi et al. 2017). MDAI induces transporter-mediated release of 5-HT and NE, similar to MDMA, but, unlike MDMA, MDAI does not induce DA release through the human DAT under the conditions investigated (Simmler et al. 2014b; Eshleman et al. 2017). 5-IAI causes 5-HT and DA release, but not NE release, although it acts as a potent NET inhibitor (Iversen et al. 2013; Simmler et al. 2014b). According to user reports, MDAI and 5-IAI cause euphoria and have entactogenic properties (Pinterova et al. 2017). Interestingly, MMAI was shown to be selective for SERT over DAT and NET when inducing uptake inhibition and transporter-mediated release (Johnson et al. 1991; Luethi et al. 2017). The lack of NET activity predicts that MMAI might not be truly experienced as MDMA-like, since NE-mediated psychostimulation is likely absent or weak in acute MMAI effects, whereas MDMA induces pronounced NE-mediated psychostimulation (Hysek et al. 2012a; Hysek et al. 2011; Hysek et al. 2010). The selective serotonergic activity could imply a high risk for serotonin syndrome, similar to 4-MTA. However, unlike 4-MTA, MMAI does not significantly inhibit MAO (Scorza et al. 1999), which might be relevant when considering the potential for severe adverse effects.

Some aminoindans were developed as potential non-neurotoxic alternatives for MDMA. MDAI was reported to substitute for MDMA, but not LSD, in drug discrimination studies in rats. However, in contrast to MDMA, MDAl did not cause 5-HT depletion (Nichols et al. 1990). Similarly, no indication for 5-HT toxicity was found for 5-IAI (Nichols et al. 1991). Non-neurotoxic effects of MDAI and 5-IAI suggested that these aminoindans might display a safer risk profile compared to MDMA but recent animal studies indicated that MDAI can induce potentially life-threatening toxicity related to the serotonin syndrome (Gatch et al. 2016; Palenicek et al. 2016). Three fatal intoxications involving MDAI and other substances have been described and from 
ante-mortem information available in one case, the involvement of serotonin toxicity was considered likely (Corkery et al. 2013).

The receptor interaction profiles of MDMA-like aminoindans show that 5-IAI exhibits nanomolar affinity at the 5- $\mathrm{HT}_{1 \mathrm{~A}^{-}}, 5-\mathrm{HT}_{2 \mathrm{~A}^{-}}$(Simmler et al. 2014b) and the 5$\mathrm{HT}_{2 B}$ receptors (Iversen et al. 2013). Furthermore, affinity $\left(\mathrm{K}_{\mathrm{i}}=1.2 \mu \mathrm{M}\right)$ for 5 -IAI was also observed at the $5-\mathrm{HT}_{2 \mathrm{C}}$ receptor (Simmler et al. 2014b). This is in contrast to MDAI, which did not exhibit affinity to these 5-HT receptors, and to MMAI, which only had activity in the micromolar range (Luethi et al. 2017).

\subsection{MDMA-like benzofurans}

The pharmacology and toxicology of benzofurans is relatively poorly explored to date, but fatal, analytically confirmed intoxication with the benzofuran 5-APB alone or in combination with 3-MMC have been reported (Adamowicz et al. 2014; Mclntyre et al. 2015). Benzofurans were described by users as substances inducing entactogenic and stimulant effects, but also sympathomimetic toxicity, including hyperthermia (Welter-Luedeke and Maurer 2016). In drug discrimination studies in rats, the 2,3dihydrobenzofurans 5-APDB and 6-APDB substituted for MDMA-like entactogens, but not for amphetamine (Monte et al. 1993).

Many benzofurans show MDMA-like pharmacological profiles. Rickli et al. (Rickli et al. 2015b) have characterized a set of benzofurans, which were all potent NET inhibitors and showed DAT/SERT ratios < 1 (Table 1). 5-APDB, 5-MAPDB, 5APB, and 6-APDB showed high selectivity for SERT over DAT inhibition with DAT/SERT ratios of 0.01-0.07. 5-EAPB and 6-APB have DAT/SERT ratios of 0.15 and 0.29 , respectively. The least selective compounds for SERT over DAT were 4-APB and 7-APB with DAT/SERT ratios of 0.46 and 0.65 . All benzofurans characterized in this study induced transporter-mediated release of one, two, or all three monoamines.

Interestingly, most benzofurans were partial agonists at the 5- $\mathrm{HT}_{2 \mathrm{~A}}$ and the 5$\mathrm{HT}_{2 \mathrm{~B}}$ receptors. 5- $\mathrm{HT}_{2 \mathrm{~A}}$ agonism of benzofurans is comparable to MDMA (activation potency of $6 \mu \mathrm{M}$ and $55 \%$ efficacy), but MDMA does not have functional activity at the 5- $\mathrm{HT}_{2 \mathrm{~B}}$ receptor (Rickli et al. 2015b). Since activation of the 5-HT2B receptor has been associated with heart valve fibrosis (Roth 2007), chronic consumption of benzofurans might pose a risk for long-term cardiotoxicity (Dawson et al. 2014). 4-APB, 6-APB, 6APBP, and 7-APB showed affinity for the $\alpha_{2 A}$-adrenoceptor in the nanomolar range $\left(K_{i}\right.$ values of $140-870 \mathrm{nM}$; (Rickli et al. 2015b), which might contribute to the sympathomimetic toxicity by augmenting vesicular NE release (Hysek et al. 2012b).

$7-A P B$ is a moderately potent human trace amine-associated receptor 1 (TAAR1) receptor agonist with an $\mathrm{EC}_{50}$ in the nanomolar range $(630 \mathrm{nM})$, similar to the endogenous ligands B-PEA $(260 \mathrm{nM})$ and $p$-tyramine $(990 \mathrm{nM})$ and more than 10fold more potent than other benzofurans (Simmler et al. 2016). The activation of human TAAR1 might diminish the effects of psychostimulation and intoxication arising from 7-APB effects on monoamine transporters (see 4.1.3. for more details). Affinity to mouse and rat TAAR1 has been shown for many psychostimulants, but species differences are common (Simmler et al. 2016). For example, 5-IT and 4-MA bind and activate TAAR1 in the nanomolar range, but do not activate human TAAR1.

\subsection{Conclusions}

Although MDMA-like substances have low abuse liability due to their selectivity for SERT over DAT, the risk for potentially life-threatening intoxication appears high 
considering serotonergic toxicity that, for some MDMA-like NPS, might be augmented due to inhibition of MAO. Sympathomimetic toxicity arising from NE action is also common. The classification into MDMA-like NPS is approximately based on DAT/SERT ratios and does not account for subtle differences in the pharmacology of NPS, such as receptor interactions or increased prevalence of 5-HT toxicity. Consequently, collecting clinical and pre-clinical information for each MDMA-like NPS is helpful for contextualizing the clinical features seen in acute toxicity cases.

\section{Amphetamine-like NPS}

\subsection{Pharmacology of amphetamine-like substances}

Subjective effects of amphetamine involve psychostimulation, euphoria, and increased arousal. Other clinical features include acute cardiotoxicity, such as hypertension, increased blood pressure, heart rate, and body temperature (Dolder et al. 2017). Regular amphetamine consumption bears a considerable risk for abuse and dependence. Amphetamine increases DA and NE levels by DAT and NET inhibition and induction of transporter-mediated release (Heal et al. 2013). Amphetamine further shows moderate affinity for the $\alpha_{2 A}$ adrenoceptor and the 5- $\mathrm{HT}_{1 \mathrm{~A}}$ receptor (Simmler et al. 2013) and is a TAAR1 ligand (Bunzow et al. 2001) with potent full agonist properties at the human TAAR1 (Simmler et al. 2016).

Non-ß-keto NPS described here as amphetamine-like show relatively good uptake inhibition potencies at SERT with DAT/SERT ratios between 1 and 6 (Table 1). In comparison to amphetamine or methamphetamine, 4-fluoroamphetamine, 4fluoromethamphetamine, $\mathrm{N}$-ethylamphetamine, and 5 -IT are less selective at DAT and NET and rather non-selective for all monoamine transporters, although about 10-fold more potent at NET than DAT and SERT. Like amphetamine, these amphetamine-like NPS also act as monoamine releasers (Simmler et al. 2014a; Rickli et al. 2015a; Luethi et al. 2017). In contrast, there are several cathinone-derivatives with DAT/SERT ratios $>10$, such as cathinone, methcathinone, or 3-fluoromethcathinone (Simmler et al. 2013; Simmler et al. 2014a), which resemble amphetamine more closely in their transporter inhibition profile.

\subsubsection{Acute dopaminergic toxicity}

Induction of rapid increase of DA level in the mesolimbic DA system is a typical acute effect of many drugs of abuse (Kehr et al. 2011), including amphetamine and cocaine, but also opioids, which have indirect effects onto the DA system (Luscher and Malenka 2011). Drug-induced increase of DA levels activates the reward system and causes euphoria (Heal et al. 2013; Sulzer 2011). Unwanted drug effects such as psychotic states and aggression can also be attributed to excessive/chronic stimulation of dopaminergic action (Harro 2015). Life-threatening excited delirium syndrome has been associated with acute dopaminergic toxicity (Mash et al. 2009).

\subsubsection{Abuse liability}


The dopamine system is crucially involved in plasticity underlying drug dependence and compulsive drug use (Luscher and Malenka 2011; Pascoli et al. 2015; Koob and Volkow 2016). Substances acting to increase DA levels via DAT inhibition and/or DA reverse transport might therefore cause dependence, possibly progressing to addiction. However, the 5-HT system can oppose dopaminergic effects (Daw et al. 2002; Alex and Pehek 2007) and serotonergic properties can lower the abuse liability of psychostimulants (Simmler et al. 2017; Suyama et al. 2016; Liechti 2015; Bauer et al. 2013; Rothman and Baumann 2006; Wee et al. 2005). Accordingly, the relative action at DAT vs. SERT is crucial for assessing abuse liability of psychostimulants (Baumann et al. 2012). From a pre-clinical perspective, high DAT/SERT ratios are generally considered indicative of a significant potential for abuse and dependence. The in vitro selectivity for DAT vs. SERT predicts the DA vs. 5-HT release as measured using in vivo microdialysis and also correlates with measures of reward such as intracranial self-stimulation thresholds as shown for a series of para-ring-substituted cathinones (Suyama et al. 2016). In addition, cathinones with a predominant action on the DA system are self-administered more readily than substances with a more 5-HT activating profile (Bonano et al. 2014; Schindler et al. 2016; Gannon et al. 2018). MDMA shows a relatively low abuse liability and has high selectivity of SERT over DAT. In the assays carried out in the authors' laboratory, the abuse dependence liability of cocaine is associated with a DAT/SERT ratio of 3.1 and amphetamine and methamphetamine have an even higher DAT/SERT ratio of >10 (Simmler et al. 2013). The amphetamine-like NPS discussed here show DAT/SERT ratios of 1-5. From the perspective of these studies, these amphetamine-like NPS might show lower abuse liability than amphetamine. However, other factors such as drug kinetics, receptor interactions, routes of administration and social context also play important roles for the clinical picture.

\subsubsection{Activation of TAAR1}

TAAR1 is a target of amphetamine and many amphetamine-derivatives. TAAR1 is involved in the regulation of DA activity (Bradaia et al. 2009) and activation of TAAR1 reduces the abuse liability of drugs such as cocaine (Pei et al. 2014; Pei et al. 2015). Amphetamine and MDMA induce more pronounced psychostimulant effects in rodents not expressing TAAR1 (Lindemann et al. 2008; Di Cara et al. 2011). Psychostimulants, which act directly on TAAR1, can therefore induce negative modulation of psychotropic effects. TAAR1 activation might have protective effect with respect to drug toxicity and abuse liability. However, species differences between the rodent TAAR1 and human TAAR1 are frequent (Simmler et al. 2016). MDMA activates rat and mouse TAAR1 with low micromolar potencies, but its activation potency for the human TAAR1 is very low. Amphetamine, in contrast, activates human TAAR1 with an $\mathrm{EC}_{50}$ of $2.8 \mu \mathrm{M}$ (Simmler et al. 2016). For the present chapter, available evidence on the activity of NPS at the human TAAR1are presented.

\subsection{4-Fluoroamphetamine, 4-fluoromethamphetamine and $\mathrm{N}$ - ethylamphetamine}

4-FA is a popular NPS and described by users to induce a mixture of amphetamineand MDMA-like effects, which include stimulation, euphoria and empathy (Linsen et al. 2015; Hondebrink et al. 2017). Despite the entactogenic properties reported for 4- 
FA, which are typical for MDMA-like substances, 4-FA has been included in this section due to its DAT/SERT ratio above a value of 1 (Wee et al. 2005; Rickli et al. 2015a; Eshleman et al. 2017). 4-FA inhibits monoamine transporters with potencies in the rank order NET > DAT > SERT (Table 1, Eshleman et al. 2017). The same rank order has also been described for the potency of 4-FA to induce monoamine release (EC50 values of $28 \mathrm{nM}$ (NE), $52 \mathrm{nM}$ (DA), and $939 \mathrm{nM}$ (5-HT) (Wee et al. 2005). Cardiotoxicity and hyperthermia are typical symptoms of sympathomimetic intoxication associated with 4-FA use, and severe headache has been increasingly reported (Hondebrink et al. 2017). Cerebral hemorrhage and severe cardiovascular toxicity were diagnosed in several cases of severe or fatal intoxications (Wijers et al. 2017; Hondebrink et al. 2017). 4-FA exhibits moderate affinity for the $\alpha_{2 A}$ adrenoceptor and shows weak to moderate binding affinity or activation potency at the $5-\mathrm{HT}_{1 \mathrm{~A}^{-}}, 5-$ $\mathrm{HT}_{2 \mathrm{~A}^{-}}, 5-\mathrm{HT}_{2 \mathrm{~B}^{-}}$, and $5-\mathrm{HT}_{2 \mathrm{C}}$ receptors. 4-FA is also a partial agonist at the human TAAR1 (Rickli et al. 2015a).

4-Fluoromethamphetamine is less frequently reported, but resembles 4-FA in its pharmacological profile at monoamine transporters and receptors (Table 1; Rickli et al. 2015a). The in vitro data suggest that clinical effects and toxicity might be similar to those reported for 4-FA. $\mathrm{N}$-Ethylamphetamine induces hyperlocomotion in mice (Tessel et al. 1975) and substitutes for amphetamine in drug-discrimination tests in rhesus monkeys (Woolverton and English 1997), which indicates stimulant-like properties of $\mathrm{N}$-ethylamphetamine. Furthermore, $\mathrm{N}$-ethylamphetamine showed reinforcing properties in rhesus monkeys (Tessel and Woods 1975). NEthylamphetamine was found to show a comparable uptake inhibition profile as 4fluoromethamphetamine (Table 1) and functioned as a releaser of DA, NE, and 5-HT (EC50 values of $2.6 \mu \mathrm{M}(\mathrm{NE}), 93 \mu \mathrm{M}$ (DA), and $43 \mu \mathrm{M}(5-\mathrm{HT})$; Tessel and Rutledge 1976). $N$-Ethylamphetamine has moderate binding affinity for the $\alpha_{2 A^{-}}, 5-\mathrm{HT}_{2 A^{-}}$, and $5-$ $\mathrm{HT}_{2 \mathrm{C}}$-receptors (Simmler et al. 2014a), but does not activate human TAAR1 (Simmler et al. 2016). Similar to 4-fluoromethamphetamine, the pharmacological profile for $\mathrm{N}$ ethylamphetamine predict effects and clinical features to be similar to 4-FA.

\subsection{5-(2-Aminopropyl)indole (5-IT)}

5-IT (5-API) has caused a considerable number of fatal intoxications since its emergence in 2012 (EMCDDA 2014). The clinical cases presented with sympathomimetic and serotonergic toxicity, including hyperthermia, cardiotoxicity, and organ failure (Bäckberg et al. 2014). 5-IT inhibits NET, DAT and SERT and 5-IT induces transporter-mediated release of NE, DA and 5-HT (Marusich et al. 2016; Luethi et al. 2017). Although 5-IT acts more potently at NET and DAT than at SERT, serotonergic toxicity has been implicated in the intoxication cases. In addition, 5-IT inhibits MAO-A (Herraiz and Brandt 2014), which can augment the rise of 5-HT levels and poses the risk for resulting in the development of the serotonin syndrome. 5-IT has affinity for the $\alpha_{1 A^{-}}$and $\alpha_{2 A}$ adrenoceptors ( $K_{i}$ of 5.4 and $1.7 \mu \mathrm{M}$, respectively; (Luethi et al. 2017), which might contribute to sympathomimetic toxicity. 5-IT is also a potent partial agonist at $5-\mathrm{HT}_{2 \mathrm{~A}}$ and $5-\mathrm{HT}_{2 \mathrm{~B}}$ receptors $\left(\mathrm{EC}_{50}\right.$ of 0.5 and $1.5 \mu \mathrm{M}$, respectively; Luethi et al. 2017), which are important for mediating hallucinogenic effects via 5-HT2A activity (Nichols 2004) and, in the long-term use, might result in heart valve fibrosis mediated via 5- $\mathrm{HT}_{2 \mathrm{~B}}$ activity (Roth 2007).

\subsection{2-Aminoindan}


The use and reported fatalities of 2-Al are relatively rare (Elliott and Evans 2014), and not much more recent information about its in vivo pharmacology and toxicology could be identified. It is worth noting that the in vitro pharmacological profile of 2-Al is distinct from the MDMA-like aminoindans 5-IAI, MDAI and MMAI (see Section 3.3.). In contrast to the MDMA-like aminoindans, 2-Al did not inhibit SERT (Table 1; Simmler et al. 2014b). 2-Al selectively inhibits NET, also inducing NE release, and at higher concentrations, also acts as a DAT inhibitor and releaser (Simmler et al. 2014b). The selectivity of 2-AI for NET over DAT at the human transporters implies that it causes psychotropic effects that may be distinct from amphetamine, since DA-mediated euphoria might be low or absent for 2-Al. However, in rat synaptosomes, 2-Al showed DAT and NET inhibition (Horn and Snyder 1972). Amphetamine-like properties of 2Al were also indicated behaviourally in rats by induction of hyperlocomotion (Mrongovius et al. 1978) and by substitution for amphetamine in drug discrimination experiments (Glennon et al. 1984). Sympathomimetic effects of 2-Al can arise from increased NE levels due to NET inhibition and NE release, and high-affinity $\left(K_{i}=450\right.$ $\mathrm{nM}$ ) binding of 2-AI to the $\alpha_{2 \mathrm{~A}}$ adrenoceptor (Simmler et al. 2014b) likely contributes to the sympathomimetic effect of 2-Al. Interestingly, 2-Al was a full agonist at the human TAAR1 with similar potency $\left(\mathrm{EC}_{50}\right.$ of $\left.1.5 \mu \mathrm{M}\right)$ similar to amphetamine $\left(\mathrm{EC}_{50}\right.$ of $\left.2.8 \mu \mathrm{M}\right)$, which also has full-agonist properties (Simmler et al. 2016).

\subsection{Conclusions}

Amphetamine-like NPS preferentially inhibit DAT and NET and act as releasers. The NPS discussed here show preference for DAT over SERT inhibition, but with lower DAT/SERT ratios than amphetamine. The receptor interaction profiles of amphetamine-like NPS vary and might contribute to drug-specific psychotropic effects and toxicity. MAO inhibition has been shown for 5-IT and suggests particular risk for fatal intoxication.

\section{Acknowledgments}

The authors would like to thank Dr. Patrick Burch for the design of Figure 1. LDS is supported by the Swiss National Science Foundation (SNSF; PZ00P3_174178). MEL is supported by the Federal Office of Public Health (16.921318) and the SNSF (320030149493 and 320030_170249).

\section{References}

Adamowicz P, Zuba D, Byrska B (2014) Fatal intoxication with 3-methyl-Nmethylcathinone (3-MMC) and 5-(2-aminopropyl)benzofuran (5-APB). Forensic Sci Int 245:126-132. doi:10.1016/j.forsciint.2014.10.016

Aerts LA, Mallaret M, Rigter H (2000) N-methyl-1-(1,3-benzodioxol-5-yl)-2-butanamine (MBDB): its properties and possible risks. Addiction biology 5 (3):269-282. doi:10.1111/j.1369-1600.2000.tb00191.x

Alex KD, Pehek EA (2007) Pharmacologic mechanisms of serotonergic regulation of dopamine neurotransmission. Pharmacol Ther 113 (2):296-320. doi:10.1016/j.pharmthera.2006.08.004

Bäckberg M, Beck O, Hulten P, Rosengren-Holmberg J, Helander A (2014) Intoxications of the new psychoactive substance 5-(2-aminopropyl)indole (5- 
IT): a case series from the Swedish STRIDA project. Clin Toxicol (Phila) 52 (6):618-624. doi:10.3109/15563650.2014.920088

Bauer CT, Banks ML, Blough BE, Negus SS (2013) Use of intracranial self-stimulation to evaluate abuse-related and abuse-limiting effects of monoamine releasers in rats. $\mathrm{Br} J$ Pharmacol 168 (4):850-862. doi:10.1111/j.14765381.2012.02214.x

Baumann MH, Ayestas MA, Jr., Partilla JS, Sink JR, Shulgin AT, Daley PF, Brandt SD, Rothman RB, Ruoho AE, Cozzi NV (2012) The designer methcathinone analogs, mephedrone and methylone, are substrates for monoamine transporters in brain tissue. Neuropsychopharmacology 37 (5):1192-1203. doi:10.1038/npp.2011.304

Baumann MH, Clark RD, Woolverton WL, Wee S, Blough BE, Rothman RB (2011) In vivo effects of amphetamine analogs reveal evidence for serotonergic inhibition of mesolimbic dopamine transmission in the rat. J Pharmacol Exp Ther 337 (1):218-225. doi:10.1124/jpet.110.176271

Baumann MH, Partilla JS, Lehner KR, Thorndike EB, Hoffman AF, Holy M, Rothman RB, Goldberg SR, Lupica CR, Sitte HH, Brandt SD, Tella SR, Cozzi NV, Schindler CW (2013) Powerful cocaine-like actions of 3,4methylenedioxypyrovalerone (MDPV), a principal constituent of psychoactive 'bath salts' products. Neuropsychopharmacology 38 (4):552-562. doi:10.1038/npp.2012.204

Baumann MH, Wang X, Rothman RB (2007) 3,4-Methylenedioxymethamphetamine (MDMA) neurotoxicity in rats: a reappraisal of past and present findings. Psychopharmacology (Berl) 189 (4):407-424. doi:10.1007/s00213-006-0322-6

Bershad AK, Miller MA, Baggott MJ, de Wit H (2016) The effects of MDMA on socioemotional processing: does MDMA differ from other stimulants? J Psychopharmacol 30:1248-1258. doi:10.1177/0269881116663120

Blakely RD, Defelice LJ, Galli A (2005) Biogenic amine neurotransmitter transporters: just when you thought you knew them. Physiology 20:225-231. doi:10.1152/physiol.00013.2005

Blanckaert P, van Amsterdam J, Brunt T, van den Berg J, Van Durme F, Maudens K, van Bussel J (2013) 4-Methyl-amphetamine: a health threat for recreational amphetamine users. J Psychopharmacol 27 (9):817-822. doi:10.1177/0269881113487950

Bonano JS, Glennon RA, De Felice LJ, Banks ML, Negus SS (2014) Abuse-related and abuse-limiting effects of methcathinone and the synthetic "bath salts" cathinone analogs methylenedioxypyrovalerone (MDPV), methylone and mephedrone on intracranial self-stimulation in rats. Psychopharmacology (Berl) 231 (1):199-207. doi:10.1007/s00213-013-3223-5

Bradaia A, Trube G, Stalder H, Norcross RD, Ozmen L, Wettstein JG, Pinard A, Buchy D, Gassmann M, Hoener MC, Bettler B (2009) The selective antagonist EPPTB reveals TAAR1-mediated regulatory mechanisms in dopaminergic neurons of the mesolimbic system. Proc Natl Acad Sci U S A 106 (47):20081-20086. doi:10.1073/pnas.0906522106

Brandt SD Braithwaite RA, Evans-Brown M, Kicman AT (2013) Aminoindane Analogues. In: Dargan PI, Wood DM (ed) Novel Psychoactive Substances: Classification, Pharmacology and Toxicology. Elsevier, 261-283. doi.org/10.1016/B978-0-12-415816-0.00011-0

Bunzow JR, Sonders MS, Arttamangkul S, Harrison LM, Zhang G, Quigley DI, Darland T, Suchland KL, Pasumamula S, Kennedy JL, Olson SB, Magenis RE, Amara 
SG, Grandy DK (2001) Amphetamine, 3,4-methylenedioxymethamphetamine, lysergic acid diethylamide, and metabolites of the catecholamine neurotransmitters are agonists of a rat trace amine receptor. Mol Pharmacol 60 (6):1181-1188. doi:10.1124/mol.60.6.1181

Carmo H, Remiao F, Carvalho F, Fernandes E, de Boer D, dos Reys LA, de Lourdes Bastos M (2003) 4-Methylthioamphetamine-induced hyperthermia in mice: influence of serotonergic and catecholaminergic pathways. Toxicology and applied pharmacology 190 (3):262-271

Colado MI, Granados R, O'Shea E, Esteban B, Green AR (1999) The acute effect in rats of 3,4-methylenedioxyethamphetamine (MDEA, "eve") on body temperature and long term degeneration of $5-\mathrm{HT}$ neurones in brain: a comparison with MDMA ("ecstasy"). Pharmacol Toxicol 84 (6):261-266

Cole JC, Sumnall HR (2003) Altered states: the clinical effects of Ecstasy. Pharmacol Ther $98(1): 35-58$

Corkery JM, Elliott S, Schifano F, Corazza O, Ghodse AH (2013) MDAI (5,6methylenedioxy-2-aminoindane; 6,7-dihydro-5H-cyclopenta[f][1,3]benzodioxol6-amine; 'sparkle'; 'mindy') toxicity: a brief overview and update. Hum Psychopharmacol 28 (4):345-355. doi:10.1002/hup.2298

Cruickshank CC, Dyer KR (2009) A review of the clinical pharmacology of methamphetamine. Addiction 104 (7):1085-1099. doi:10.1111/j.13600443.2009.02564.x

Daw ND, Kakade S, Dayan P (2002) Opponent interactions between serotonin and dopamine. Neural networks : the official journal of the International Neural Network Society 15 (4-6):603-616. doi:10.1016/S0893-6080(02)00052-7

Dawson P, Opacka-Juffry J, Moffatt JD, Daniju Y, Dutta N, Ramsey J, Davidson C (2014) The effects of benzofury (5-APB) on the dopamine transporter and 5HT2-dependent vasoconstriction in the rat. Prog Neuropsychopharmacol Biol Psychiatry 48:57-63. doi:10.1016/j.pnpbp.2013.08.013

Di Cara B, Maggio R, Aloisi G, Rivet JM, Lundius EG, Yoshitake T, Svenningsson P, Brocco M, Gobert A, De Groote L, Cistarelli L, Veiga S, De Montrion C, Rodriguez M, Galizzi JP, Lockhart BP, Coge F, Boutin JA, Vayer P, Verdouw PM, Groenink L, Millan MJ (2011) Genetic deletion of trace amine 1 receptors reveals their role in auto-inhibiting the actions of ecstasy (MDMA). J Neurosci 31 (47):16928-16940. doi:10.1523/JNEUROSCI.2502-11.2011

Dolder PC, Strajhar P, Vizeli P, Hammann F, Odermatt A, Liechti ME (2017) Pharmacokinetics and Pharmacodynamics of Lisdexamfetamine Compared with D-Amphetamine in Healthy Subjects. Front Pharmacol 8:617. doi:10.3389/fphar.2017.00617

Dukat M, Young R, Glennon RA (2002) Effect of PMA optical isomers and 4-MTA in PMMA-trained rats. Pharmacol Biochem Behav 72 (1-2):299-305. doi:10.1016/S0091-3057(01)00776-6

Elliott S, Evans J (2014) A 3-year review of new psychoactive substances in casework. Forensic Sci Int 243:55-60. doi:10.1016/j.forsciint.2014.04.017

EMCDDA (2014) Report on the risk assessment of 5-(2-aminopropyl)indole in the framework of the Council Decision on new psychoactive substances, Risk Assessment, Publications Office of the European Union, Luxembourg. doi: $10.2810 / 21296$

EMCDDA (2016) European drug report 2016. European Monitoring Centre for Drugs and Drug Addiction (EMCDDA), Luxembourg. doi:10.2810/084165 
Eshleman AJ, Wolfrum KM, Reed JF, Kim SO, Swanson T, Johnson RA, Janowsky A (2017) Structure-activity relationships of substituted cathinones, with transporter binding, uptake, and release. J Pharmacol Exp Ther 360 (1):33-47. doi:10.1124/jpet.116.236349

Gannon BM, Sulima A, Rice KC, Collins GT (2018) Inhibition of Cocaine and 3,4Methylenedioxypyrovalerone (MDPV) Self-Administration by Lorcaserin Is Mediated by 5-HT2C Receptors in Rats. J Pharmacol Exp Ther 364 (2):359366. doi:10.1124/jpet.117.246082

Gatch MB, Dolan SB, Forster MJ (2016) Locomotor, discriminative stimulus, and place conditioning effects of MDAI in rodents. Behav Pharmacol 27 (6):497-505. doi:10.1097/FBP.0000000000000237

Gillman PK (2005) Monoamine oxidase inhibitors, opioid analgesics and serotonin toxicity. Br J Anaesth 95 (4):434-441. doi:10.1093/bja/aei210

Glennon RA, Young R, Dukat M, Chang-Fong J, El-Zahabi M (2007) N-Methyl-1-(4methoxyphenyl)-2-aminopropane (PMMA) and N-Methyl-1-(3,4methylenedioxyphenyl)-2-aminopropane (MDMA) produce non-identical discriminative stimuli in rats. Pharmacol Biochem Behav 86 (3):477-484. doi:10.1016/j.pbb.2007.01.007

Glennon RA, Young R, Hauck AE, McKenney JD (1984) Structure-activity studies on amphetamine analogs using drug discrimination methodology. Pharmacol Biochem Behav 21 (6):895-901

Glennon RA, Yousif M, Patrick G (1988) Stimulus properties of 1-(3,4methylenedioxyphenyl)-2-aminopropane (MDA) analogs. Pharmacol Biochem Behav 29 (3):443-449

Harro J (2015) Neuropsychiatric Adverse Effects of Amphetamine and Methamphetamine. International review of neurobiology 120:179-204. doi:10.1016/bs.irn.2015.02.004

Hartung TK, Schofield E, Short AI, Parr MJ, Henry JA (2002) Hyponatraemic states following 3,4-methylenedioxymethamphetamine (MDMA, 'ecstasy') ingestion. QJM 95 (7):431-437

Heal DJ, Smith SL, Gosden J, Nutt DJ (2013) Amphetamine, past and present--a pharmacological and clinical perspective. J Psychopharmacol 27 (6):479-496. doi:10.1177/0269881113482532

Herraiz T, Brandt SD (2014) 5-(2-Aminopropyl)indole (5-IT): a psychoactive substance used for recreational purposes is an inhibitor of human monoamine oxidase (MAO). Drug Test Anal 6 (7-8):607-613. doi:10.1002/dta.1530

Hill SL, Thomas SH (2011) Clinical toxicology of newer recreational drugs. Clin Toxicol (Phila) 49 (8):705-719. doi:10.3109/15563650.2011.615318

Holden R, Jackson MA (1996) Near-fatal hyponatraemic coma due to vasopressin over-secretion after "ecstasy" (3,4-MDMA). Lancet 347 (9007):1052

Hondebrink L, Nugteren-van Lonkhuyzen JJ, Rietjens SJ, Brunt TM, Venhuis B, Soerdjbalie-Maikoe V, Smink BE, van Riel A, de Vries I (2017) Fatalities, Cerebral Hemorrhage, and Severe Cardiovascular Toxicity After Exposure to the New Psychoactive Substance 4-Fluoroamphetamine: A Prospective Cohort Study. Ann Emerg Med. doi:10.1016/j.annemergmed.2017.07.482

Horn AS, Snyder SH (1972) Steric requirements for catecholamine uptake by rat brain synaptosomes: studies with rigid analogs of amphetamine. J Pharmacol Exp Ther 180 (3):523-530

Hysek CM, Schmid Y, Rickli A, Simmler LD, Donzelli M, Grouzmann E, Liechti ME (2012a) Carvedilol inhibits the cardiostimulant and thermogenic effects of 
MDMA in humans. Br J Pharmacol 166 (8):2277-2288. doi:10.1111/j.14765381.2012.01936.x

Hysek CM, Brugger R, Simmler LD, Bruggisser M, Donzelli M, Grouzmann E, Hoener MC, Liechti ME (2012b) Effects of the alpha(2)-adrenergic agonist clonidine on the pharmacodynamics and pharmacokinetics of 3,4methylenedioxymethamphetamine in healthy volunteers. J Pharmacol Exp Ther 340 (2):286-294. doi:10.1124/jpet.111.188425

Hysek CM, Schmid Y, Simmler LD, Domes G, Heinrichs M, Eisenegger C, Preller KH, Quednow BB, Liechti ME (2014a) MDMA enhances emotional empathy and prosocial behavior. Social cognitive and affective neuroscience 9 (11):16451652. doi:10.1093/scan/nst161

Hysek CM, Simmler LD, Ineichen M, Grouzmann E, Hoener MC, Brenneisen R, Huwyler J, Liechti ME (2011) The norepinephrine transporter inhibitor reboxetine reduces stimulant effects of MDMA ("ecstasy") in humans. Clin Pharmacol Ther 90 (2):246-255. doi:10.1038/clpt.2011.78

Hysek CM, Simmler LD, Nicola VG, Vischer N, Donzelli M, Krahenbuhl S, Grouzmann E, Huwyler J, Hoener MC, Liechti ME (2012c) Duloxetine inhibits effects of MDMA ("Ecstasy") in vitro and in humans in a randomized placebo-controlled laboratory study. PLoS One 7 (5):e36476. doi:10.1371/journal.pone.0036476

Hysek CM, Simmler LD, Schillinger N, Meyer N, Schmid Y, Donzelli M, Grouzmann E, Liechti ME (2014b) Pharmacokinetic and pharmacodynamic effects of methylphenidate and MDMA administered alone or in combination. Int $\mathrm{J}$ Neuropsychopharmacol 17 (3):371-381. doi:10.1017/S1461145713001132

Hysek CM, Vollenweider FX, Liechti ME (2010) Effects of a beta-blocker on the cardiovascular response to MDMA (Ecstasy). Emerg Med J 27 (8):586-589. doi:10.1136/emj.2009.079905

Iversen L, Gibbons S, Treble R, Setola V, Huang XP, Roth BL (2013) Neurochemical profiles of some novel psychoactive substances. Eur J Pharmacol 700 (13):147-151. doi:10.1016/j.ejphar.2012.12.006

Johnson MP, Conarty PF, Nichols DE (1991) [3H]monoamine releasing and uptake inhibition properties of 3,4-methylenedioxymethamphetamine and $p$ chloroamphetamine analogues. Eur J Pharmacol 200 (1):9-16

Kehr J, Ichinose F, Yoshitake S, Goiny M, Sievertsson T, Nyberg F, Yoshitake T (2011) Mephedrone, compared to MDMA (ecstasy) and amphetamine, rapidly increases both dopamine and serotonin levels in nucleus accumbens of awake rats. Br J Pharmacol. doi:10.1111/j.1476-5381.2011.01499.x

Koob GF, Volkow ND (2016) Neurobiology of addiction: a neurocircuitry analysis. Lancet Psychiatry 3 (8):760-773. doi:10.1016/S2215-0366(16)00104-8

Liechti M (2015) Novel psychoactive substances (designer drugs): overview and pharmacology of modulators of monoamine signaling. Swiss medical weekly 145:w14043. doi:10.4414/smw.2015.14043

Liechti ME (2014) Effects of MDMA on body temperature in humans. Temperature (Austin) 1 (3):192-200. doi:10.4161/23328940.2014.955433

Liechti ME, Gamma A, Vollenweider FX (2001) Gender differences in the subjective effects of MDMA. Psychopharmacology (Berl) 154 (2):161-168

Liechti ME, Saur MR, Gamma A, Hell D, Vollenweider FX (2000) Psychological and physiological effects of MDMA ("Ecstasy") after pretreatment with the 5-HT(2) antagonist ketanserin in healthy humans. Neuropsychopharmacology 23 (4):396-404. doi:10.1016/S0893-133X(00)00126-3 
Lindemann L, Meyer CA, Jeanneau K, Bradaia A, Ozmen L, Bluethmann H, Bettler B, Wettstein JG, Borroni E, Moreau JL, Hoener MC (2008) Trace amineassociated receptor 1 modulates dopaminergic activity. J Pharmacol Exp Ther 324 (3):948-956. doi:10.1124/jpet.107.132647

Linsen F, Koning RP, van Laar M, Niesink RJ, Koeter MW, Brunt TM (2015) 4Fluoroamphetamine in the Netherlands: more than a one-night stand. Addiction 110 (7):1138-1143. doi:10.1111/add.12932

Luethi D, Kolaczynska KE, Docci L, Krahenbuhl S, Hoener MC, Liechti ME (2017) Pharmacological profile of mephedrone analogs and related new psychoactive substances. Neuropharmacology. doi:10.1016/j.neuropharm.2017.07.026

Lurie Y, Gopher A, Lavon O, Almog S, Sulimani L, Bentur Y (2012) Severe paramethoxymethamphetamine (PMMA) and paramethoxyamphetamine (PMA) outbreak in Israel. Clin Toxicol (Phila) 50 (1):39-43. doi:10.3109/15563650.2011.635148

Luscher C, Malenka RC (2011) Drug-evoked synaptic plasticity in addiction: from molecular changes to circuit remodeling. Neuron 69 (4):650-663. doi:10.1016/j.neuron.2011.01.017

Marusich JA, Antonazzo KR, Blough BE, Brandt SD, Kavanagh PV, Partilla JS, Baumann $\mathrm{MH}$ (2016) The new psychoactive substances 5-(2aminopropyl)indole (5-IT) and 6-(2-aminopropyl)indole (6-IT) interact with monoamine transporters in brain tissue. Neuropharmacology 101:68-75. doi:10.1016/j.neuropharm.2015.09.004

Mash DC, Duque L, Pablo J, Qin Y, Adi N, Hearn WL, Hyma BA, Karch SB, Druid H, Wetli CV (2009) Brain biomarkers for identifying excited delirium as a cause of sudden death. Forensic Sci Int 190 (1-3):e13-19. doi:10.1016/j.forsciint.2009.05.012

Matsumoto T, Maeno Y, Kato H, Seko-Nakamura Y, Monma-Ohtaki J, Ishiba A, Nagao M, Aoki Y (2014) 5-hydroxytryptamine- and dopamine-releasing effects of ringsubstituted amphetamines on rat brain: a comparative study using in vivo microdialysis. Eur Neuropsychopharmacol $24 \quad$ (8):1362-1370. doi:10.1016/j.euroneuro.2014.04.009

Mclntyre IM, Gary RD, Trochta A, Stolberg S, Stabley R (2015) Acute 5-(2aminopropyl)benzofuran (5-APB) intoxication and fatality: a case report with postmortem concentrations. J Anal Toxicol 39 (2):156-159. doi:10.1093/jat/bku131

Monte AP, Marona-Lewicka D, Cozzi NV, Nichols DE (1993) Synthesis and pharmacological examination of benzofuran, indan, and tetralin analogues of 3,4-(methylenedioxy)amphetamine. J Med Chem 36 (23):3700-3706

Mrongovius RI, Bolt AG, Hellyer RO (1978) Comparison of the anorectic and motor activity effects of some aminoindanes, 2-aminotetralin and amphetamine in the rat. Clin Exp Pharmacol Physiol 5 (6):635-640

Nichols DE (1986) Differences between the mechanism of action of MDMA, MBDB, and the classic hallucinogens. Identification of a new therapeutic class: entactogens. Journal of psychoactive drugs 18 (4):305-313. doi:10.1080/02791072.1986.10472362

Nichols DE (2004) Hallucinogens. Pharmacol Ther 101 (2):131-181. doi:10.1016/j.pharmthera.2003.11.002

Nichols DE (2017) Chemistry and Structure-Activity Relationships of Psychedelics. Curr Top Behav Neurosci. doi:10.1007/7854_2017_475 
Nichols DE, Brewster WK, Johnson MP, Oberlender R, Riggs RM (1990) Nonneurotoxic tetralin and indan analogues of 3,4(methylenedioxy)amphetamine (MDA). J Med Chem 33 (2):703-710

Nichols DE, Johnson MP, Oberlender R (1991) 5-lodo-2-aminoindan, a nonneurotoxic analogue of $p$-iodoamphetamine. Pharmacol Biochem Behav 38 (1):135-139

Palenicek T, Lhotkova E, Zidkova M, Balikova M, Kuchar M, Himl M, Miksatkova P, Cegan M, Vales K, Tyls F, Horsley RR (2016) Emerging toxicity of 5,6methylenedioxy-2-aminoindane (MDAI): Pharmacokinetics, behaviour, thermoregulation and LD50 in rats. Prog Neuropsychopharmacol Biol Psychiatry 69:49-59. doi:10.1016/j.pnpbp.2016.04.004

Pascoli V, Terrier J, Hiver A, Luscher C (2015) Sufficiency of mesolimbic dopamine neuron stimulation for the progression to addiction. Neuron. doi:10.1016/j.neuron.2015.10.017

Pei Y, Lee J, Leo D, Gainetdinov RR, Hoener MC, Canales JJ (2014) Activation of the trace amine-associated receptor 1 prevents relapse to cocaine seeking. Neuropsychopharmacology 39 (10):2299-2308. doi:10.1038/npp.2014.88

Pei Y, Mortas P, Hoener MC, Canales JJ (2015) Selective activation of the trace amine-associated receptor 1 decreases cocaine's reinforcing efficacy and prevents cocaine-induced changes in brain reward thresholds. Prog Neuropsychopharmacol Biol $\quad$ Psychiatry doi:10.1016/j.pnpbp.2015.05.014

Pinterova N, Horsley RR, Palenicek T (2017) Synthetic Aminoindanes: A Summary of Existing Knowledge. Frontiers in psychiatry 8:236. doi:10.3389/fpsyt.2017.00236

Prosser JM, Nelson LS (2012) The toxicology of bath salts: a review of synthetic cathinones. J Med Toxicol 8 (1):33-42. doi:10.1007/s13181-011-0193-z

Rickli A, Hoener MC, Liechti ME (2015a) Monoamine transporter and receptor interaction profiles of novel psychoactive substances: para-halogenated amphetamines and pyrovalerone cathinones. Eur Neuropsychopharmacol 25 (3):365-376. doi:10.1016/j.euroneuro.2014.12.012

Rickli A, Kopf S, Hoener MC, Liechti ME (2015b) Pharmacological profile of novel $\begin{array}{lllll}\text { psychoactive benzofurans. } \mathrm{Br} & \mathrm{J} & \text { Pharmacol } & 172 & \text { (13):3412-3425. }\end{array}$ doi:10.1111/bph.13128

Rickli A, Luethi D, Reinisch J, Buchy D, Hoener MC, Liechti ME (2015c) Receptor interaction profiles of novel N-2-methoxybenzyl (NBOMe) derivatives of 2,5dimethoxy-substituted phenethylamines (2C drugs). Neuropharmacology 99:546-553. doi:10.1016/j.neuropharm.2015.08.034

Roth BL (2007) Drugs and valvular heart disease. N Engl J Med 356 (1):6-9. doi:10.1056/NEJMp068265

Rothman RB, Baumann MH (2006) Balance between dopamine and serotonin release modulates behavioral effects of amphetamine-type drugs. Ann N Y Acad Sci 1074:245-260. doi:10.1196/annals.1369.064

Sainsbury PD, Kicman AT, Archer RP, King LA, Braithwaite RA (2011) Aminoindanes-the next wave of 'legal highs'? Drug Test Anal 3 (7-8):479-482. doi:10.1002/dta.318

Schindler CW, Thorndike EB, Goldberg SR, Lehner KR, Cozzi NV, Brandt SD, Baumann MH (2016) Reinforcing and neurochemical effects of the "bath salts" constituents 3,4-methylenedioxypyrovalerone (MDPV) and 3,4methylenedioxy- $\mathrm{N}$-methylcathinone (methylone) in male rats. 
Psychopharmacology (Berl) 233 (10):1981-1990. doi:10.1007/s00213-0154057-0

Schmid Y, Hysek CM, Simmler LD, Crockett MJ, Quednow BB, Liechti ME (2014) Differential effects of MDMA and methylphenidate on social cognition. $J$ Psychopharmacol 28 (9):847-856. doi:10.1177/0269881114542454

Scorza C, Silveira R, Nichols DE, Reyes-Parada M (1999) Effects of 5-HT-releasing agents on the extracellullar hippocampal 5-HT of rats. Implications for the development of novel antidepressants with a short onset of action. Neuropharmacology 38 (7):1055-1061

Simmler LD, Anacker AMJ, Levin MH, Vaswani NM, Gresch PJ, Nackenoff AG, Anastasio NC, Stutz SJ, Cunningham KA, Wang J, Zhang B, Henry LK, Stewart A, Veenstra-VanderWeele J, Blakely RD (2017) Blockade of the 5-HT transporter contributes to the behavioural, neuronal and molecular effects of cocaine. Br J Pharmacol 174 (16):2716-2738. doi:10.1111/bph.13899

Simmler LD, Buchy D, Chaboz S, Hoener MC, Liechti ME (2016) In vitro characterization of psychoactive substances at rat, mouse, and human trace amine-associated receptor 1. J Pharmacol Exp Ther 357 (1):134-144. doi:10.1124/jpet.115.229765

Simmler LD, Buser TA, Donzelli M, Schramm Y, Dieu LH, Huwyler J, Chaboz S, Hoener MC, Liechti ME (2013) Pharmacological characterization of designer cathinones in vitro. $\mathrm{Br} \mathrm{J}$ Pharmacol 168 (2):458-470. doi:10.1111/j.14765381.2012.02145.x

Simmler LD, Hysek CM, Liechti ME (2011) Sex Differences in the Effects of MDMA (Ecstasy) on Plasma Copeptin in Healthy Subjects. J Clin Endocrinol Metab 96 (9):2844-2850. doi:10.1210/jc.2011-1143

Simmler LD, Rickli A, Hoener MC, Liechti ME (2014a) Monoamine transporter and receptor interaction profiles of a new series of designer cathinones. Neuropharmacology 79:152-160. doi:10.1016/j.neuropharm.2013.11.008

Simmler LD, Rickli A, Schramm Y, Hoener MC, Liechti ME (2014b) Pharmacological profiles of aminoindanes, piperazines, and pipradrol derivatives. Biochemical pharmacology 88 (2):237-244. doi:10.1016/j.bcp.2014.01.024

Sprague JE, Brutcher RE, Mills EM, Caden D, Rusyniak DE (2004) Attenuation of 3,4methylenedioxymethamphetamine (MDMA, Ecstasy)-induced rhabdomyolysis with alpha1- plus beta3-adrenoreceptor antagonists. $\mathrm{Br} \mathrm{J}$ Pharmacol 142 (4):667-670. doi:10.1038/sj.bjp.0705823

Sulzer D (2011) How addictive drugs disrupt presynaptic dopamine neurotransmission. Neuron 69 (4):628-649. doi:10.1016/j.neuron.2011.02.010

Suyama JA, Sakloth F, Kolanos R, Glennon RA, Lazenka MF, Negus SS, Banks ML (2016) Abuse-Related Neurochemical Effects of Para-Substituted Methcathinone Analogs in Rats: Microdialysis Studies of Nucleus Accumbens Dopamine and Serotonin. J Pharmacol Exp Ther 356 (1):182-190. doi:10.1124/jpet.115.229559

Tessel RE, Rutledge CO (1976) Specificity of release of biogenic amines from isolated rat brain tissue as a function of the meta substituent of N-ethylamphetamine derivatives. J Pharmacol Exp Ther 197 (2):253-262

Tessel RE, Woods JH (1975) Fenfluramine and N-ethyl amphetamine: comparison of the reinforcing and rate-decreasing actions in the rhesus monkey. Psychopharmacologia 43 (3):239-244 
Tessel RE, Woods JH, Counsell RE, Lu M (1975) Structure-activity relationships between meta-substituted $\mathrm{N}$-ethylamphetamines and locomotor activity in mice. J Pharmacol Exp Ther 192 (2):310-318

Torres GE, Gainetdinov RR, Caron MG (2003) Plasma membrane monoamine transporters: structure, regulation and function. Nat Rev Neurosci 4 (1):13-25. doi:10.1038/nrn1008

Verrico CD, Miller GM, Madras BK (2007) MDMA (Ecstasy) and human dopamine, norepinephrine, and serotonin transporters: implications for MDMA-induced neurotoxicity and treatment. Psychopharmacology (Berl) 189 (4):489-503. doi:10.1007/s00213-005-0174-5

Vevelstad M, Oiestad EL, Middelkoop G, Hasvold I, Lilleng P, Delaveris GJ, Eggen T, Morland J, Arnestad M (2012) The PMMA epidemic in Norway: comparison of fatal and non-fatal intoxications. Forensic Sci Int 219 (1-3):151-157. doi:10.1016/j.forsciint.2011.12.014

Vizeli P, Liechti ME (2017) Safety pharmacology of acute MDMA administration in healthy subjects. J Psychopharmacol 31 (5):576-588. doi:10.1177/0269881117691569

Wee S, Anderson KG, Baumann MH, Rothman RB, Blough BE, Woolverton WL (2005) Relationship between the serotonergic activity and reinforcing effects of a series of amphetamine analogs. J Pharmacol Exp Ther 313 (2):848-854. doi:10.1124/jpet.104.080101

Welter-Luedeke J, Maurer HH (2016) New Psychoactive Substances: Chemistry, Pharmacology, Metabolism, and Detectability of Amphetamine Derivatives With Modified Ring Systems. Ther Drug Monit 38 (1):4-11. doi:10.1097/FTD.0000000000000240

Wijers CH, van Litsenburg RT, Hondebrink L, Niesink RJ, Croes EA (2017) Acute toxic effects related to 4-fluoroamphetamine. Lancet 389 (10069):600. doi:10.1016/S0140-6736(17)30281-7

Woolverton WL, English JA (1997) Effects of some phenylethylamines in rhesus monkeys trained to discriminate (+)-amphetamine from saline. Drug Alcohol Depend 44 (2-3):79-85

Zwartsen A, Verboven AHA, van Kleef R, Wijnolts FMJ, Westerink RHS, Hondebrink $L$ (2017) Measuring inhibition of monoamine reuptake transporters by new psychoactive substances (NPS) in real-time using a high-throughput, fluorescence-based assay. Toxicol In Vitro 45 (Pt 1):60-71. doi:10.1016/j.tiv.2017.05.010 
<smiles>CC(N)Cc1ccccc1</smiles>

Amphetamine<smiles>Cc1ccc(CC(C)N)cc1</smiles>

4-MA<smiles>CC(N)Cc1ccc(F)cc1</smiles>

4-Fluoroamphetamine<smiles>CC(N)C(=O)c1ccccc1</smiles>

Cathinone<smiles>COc1ccc(CC(C)N)cc1</smiles>

PMA<smiles>NC1Cc2ccccc2C1</smiles>

2-AI<smiles>CNC(C)Cc1ccc2c(c1)OCO2</smiles>

MDMA<smiles>CC(N)Cc1ccc2[nH]ccc2c1</smiles><smiles>CC(N)Cc1ccc2occc2c1</smiles>

Figure 1: Chemical structures of amphetamine, MDMA and selected NPS. 
Table 1: Uptake inhibition potencies of MDMA, amphetamine, methamphetamine, and selected MDMA- and amphetaminelike NPS in alphabetical order. Experiments were conducted in vitro with cultured cells that express the human NET, DAT, or SERT. All substances were tested as racemic mixtures except for D-amphetamine.

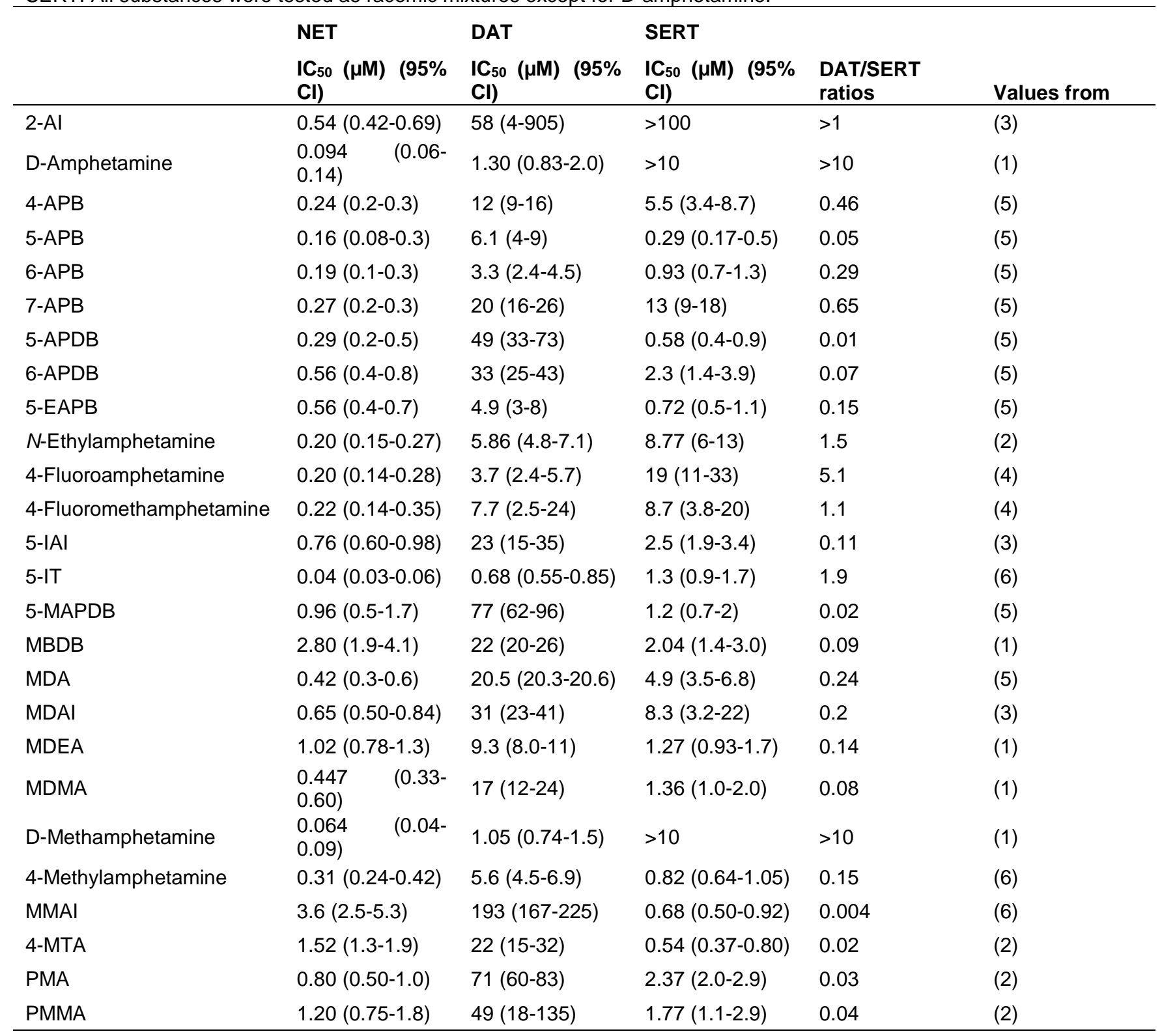
(1) Simmler et al., 2013
(4) Rickli et al., 2015a
(2) Simmler et al., 2014a
(5) Rickli et al., 2015b
(3) Simmler et al., 2014b
(6) Luethi et al., 2017 